\title{
Analisis Faktor Kepatuhan Lansia dalam Pemanfaatan Pelayanan Posyandu Lansia di Banjar Wangaya Kaja Denpasar Utara
}

\author{
Ni Kadek Muliawati ${ }^{1}$, Nurul Faidah ${ }^{2}$ \\ ${ }^{1,2}$ Sekolah Tinggi Ilmu Kesehatan Wira Medika Bali \\ Email: Muliawati.wika@gmail.com
}

Submitted : 16/11/2020

Accepted: 10/09/2021

Published: 15/09/2021

\begin{abstract}
There are 901 million people aged 60 years or over, comprising 12\% of the world's population (Department of Economic and Social Affairs, 2015). The Morbidity rate in the elderly in 2015 was $28.62 \%$, which means that for every 100 elderly people, 28 people are sick (Kemenkes RI, 2017). The utilization of health services in the elderly Posyandu is still far from the expected target. (Aprilia, 2019): out of 105 elderly, 65.7\% do not regularly go to Posyandu in Pekanbaru. The data on elderly visits to the Banjar WangayaKaja elderly posyandu in the last three months were 41 elderly (29.31\%). This study aims to analyze the obedience factor of the elderly in the utilization of posyandu services for the elderly. A cross-sectional study was conducted in Banjar WangayaKaja, Denpasar Utara in October-November 2019. The sample was 99 elderly with non-probability sampling technique, namely purposive sampling. Elderly who changed residence, were sick / hospitalized and totally dependent were not sampled. Demographic data, the distance from the elderly's house to the elderly posyandu and the knowledge of the elderly were obtained by distributing questionnaires, the attendance of the elderly was obtained based on attendance in the past one year. Multivariate analysis with logistic regression was carried out to obtain POR. There was a relationship between POR age $=0.17$ (95\% CI: 0.03-0.94), education POR $=2.71$ (95\% CI: 1.23-6.01) and the role of cadres POR $=59,64$ (95\% CI: 9,18-387,41) with elderly compliance in the utilization of posyandu services for the elderly. Factors that were not statistically found to be associated were gender ( $p$-value: 0.552), occupation ( $p$-value: 0.490), location distance to elderly posyandu (p-value: 0.009) and knowledge (p-value: 0.894). Cadres further enhance their roles, such as conducting home visits, as motivators as an effort to improve posyandu services for the elderly.
\end{abstract}

Keywords: compliance, elderly, posyandu

\section{Abstrak}

Terdapat 901 juta orang berusia 60 tahun atau lebih, yang terdiri atas $12 \%$ dari jumlah populasi dunia. Angka kesakitan pada lansia di tahun 2015 sebesar 28,62\% yang berarti pada setiap 100 lansia, terdapat 28 orang yang s akit. Pemanfaatan pelayanan Kesehatan di Posyandu lansia masih sangat jauh dari target yang diharapkan. Penelitian Aprilia di Pekanbaru, dari105 lansia, sebanyak $65,7 \%$ tidak rutin ke Posyandu Lansia. Data kunjungan lansia ke Posyandu lansia Banjar Wangaya Kaja dalam tiga bulan terakhir yaitu 41 lansia (29,31\%). Penelitian ini bertujuan untuk menganalisis faktor kepatuhan lansia dalam pemanfaatan pelayanan posyandu lansia. Studi cross sectional dilaksanakan di Banjar Wangaya Kaja Denpasar Utara pada bulan Oktober-November 2019. Sampel sebanyak 99 lansia dengan teknik non probability sampling yaitu purposive sampling. Lansia yang berpindah tempat tinggal, sakit/dirawat di RS dan ketergantungan total tidak dijadikan sampel. Data demografi, jarak rumah lansia keposyandu lansia dan pengetahuan lansia diperoleh dengan menyebar kuesioner, kehadiran lansia diperoleh berdasarkan absensi kehadiran selama satu tahun terakhir. Analisis multivariate dengan regresi logistik dilakukan untuk mendapatkan POR. Terdapat hubungan antara usia POR=0,17 (95\%CI:0,03-0,94), pendidikan $\mathrm{POR}=2,71$ (95\%CI:1,23-6,01) dan peran kader POR=59,64 (95\%CI:9,18-387,41) dengan kepatuhan lansia dalam pemanfaatan pelayanan Posyandu lansia. Faktor yang secara statistik tidak ditemukan berhubungan adalah jenis kelamin ( $\mathrm{p}$ value: 0,552$)$, pekerjaan ( $\mathrm{p}$-value: 0,490$)$, jarak lokasi keposyandu lansia (p-value: 0,009) dan pengetahuan (p-value: 0,894). Kader lebih 
meningkatkan perannya seperti melakukan kunjungan rumah, sebagai motivator sebagai salah satu upaya meningkatkan pelayanan posyandu lansia.

Kata Kunci: kepatuhan, lansia, posyandu

\section{PENDAHULUAN}

Lanjut usia adalah kelompok manusia yang berusia 60 tahun keatas(Kementrian Kesehatan RI, 2014). Berdasarkan data World Population Prospects terdapat 901 juta orang berusia 60 tahun atau lebih, yang terdiri atas $12 \%$ dari jumlah populasi dunia(Departemen of Economic and Social Affairs, 2015). Pada tahap ini individu banyak mengalami masalah perubahan dari segi kesehatan. Kesehatan pada lansia diarahkan untuk memelihara dan meningkatkan kesehatan lansia agar tetap produktif, sehat, bahagia dan berdaya guna (Maryam, 2008). Menurut kesepakatan PBB lanjut usia adalah diatas 60 tahun keatas, klasifikasi lebih lanjut oldest old dengan usia diatas 80 tahun, centenarian dengan usia diatas 100 tahun dan super centenarian usia diatas 110 tahun(WHO, 2017). Hasil proyeksi menunjukkan bahwa jumlah penduduk lanjut usia (lansia) mengalami peningkatan sekitar 48,19 juta jiwa pada tahun 2035 (Kementrian Kesehatan RI, 2017). Tren ini diperkirakan akan terus berlanjut mengingat menurunnya angka fertilitas dan meningkatnya angka harapan hidup di Indonesia. Data dari Kementerian Kesehatan Republik Indonesia, angka kesakitan pada lansia di tahun 2015 sebesar $28,62 \%$ yang berarti pada setiap 100 lansia, terdapat 28 orang yang sakit(Kementerian Kesehatan RI, 2017). Undang-undang Nomor 36 tahun 2009 Bab VII bagian ketiga pasal 138 ayat 1 dan 2 menyatakan bahwa upaya pemeliharaan kesehatan bagi lanjut usia harus ditunjukan untuk menjaga agar tetap hidup sehat dan produktif secara social maupun ekonomis sesuai dengan martabat kemanusiaan khususnya posyandu lansia.

Posyandu lansia adalah pos pelayanan untuk masyarakat lanjut usia di suatu wilayah tertentu yang sudah disepakati yang digerakkan oleh masyarakat dimana mereka bisa mendapatkan pelayanan kesehatan. Kegiatan dari posyandu lansia meliputi preventif, promotif, kuratif, dan rehabilitatif (Sulistyorini, 2010). Posyandu lansia dilaksanakan setiap satu bulan sekali yang berarti jumlah kehadiran maksimal seseorang lansia untuk menghadiri posyandu lansia yaitu dua belas kali dalam setahun (Kementrian Kesehatan RI, 2017). Tujuan dari posyandu adalah untuk meningkatkan atau mempertahankan derajat kesehatan lansia sehingga bisa hidup mandiri dan tidak menjadi beban keluarga, masyarakat dan negara (Kementrian Kesehatan RI, 2017)Keberhasilan dalam kegiatan pemanfaatan pelayanan dalam posyandu lansia tidak terlepas dari kehadiran lansia tersebut dalam mengikuti posyandu lansia.

Ada beberapa faktor yang mempengaruhi pemanfataan posyandu lansia antara lain umur, jenis kelamin, pendidikan, pekerjaan, pengetahuan, petugas kesehatan/kader, jarak rumah dan dukungan keluarga (Sulistyorini, 2010).Jumlah Posyandu Lansia yang dibina oleh puskesmas yang tersebar di seluruh provinsi di Indonesia Lebih dari 100.000 buah(Kementrian Kesehatan RI, 2019). Pemanfaatan pelayanan Kesehatan di Posyandu lansia masih sangat jauh dari target yang diharapkan. Beberapa penelitian mendapatkan hasil, dari 105 lansia, sebanyak $65,7 \%$ tidak rutin ke Posyandu(Aprilla, 2019) di Pekanbaru, dan dari 114 lansia hanya $16 \%$ yang rutin hadir Ke posyandu lansia(Amaral, 2017) di Malang. Beberapa faktor yang mempengaruhi dukungan keluarga, Pengetahuan, Tempat tinggal, peran kader(Bukit, 2019) (Aprilla, 2019) 
beberapa factor dengan hasil belum konsisten.

Hasil studi pendahuluan yang dilakukan di Banjar Wangaya Kaja, Desa Dauh Puri Kaja, Kota Denpasar di Wilayah Kerja Puskesmas III Denpasar Utara terdapat 114 lansia. Data kunjungan lansia ke posyandu lansia Banjar Wangaya Kaja dalam tiga bulan terakhir yaitu sebanyak 41 lansia $(29,31 \%)$. Dilihat dari persentase tiap bulan kehadiran lansia Banjar Wangaya Kaja ke posyandu lansia membuktikan bahwa pemanfaatan pelayanan kesehatan di posyandu lansia masih sangat jauh dari target yang diharapkan yaitu $80 \%$. Berdasarkan latar belakang tersebut maka peneliti tertarik untuk melakukan penelitian dengan judul analisis faktor kepatuhan lansia dalam pemanfaatan pelayanan posyandu lansia di Banjar Wangaya Kaja.

\section{METODE PENELITIAN}

Penelitian ini menggunakan studi cross sectional, dilaksanakan di Banjar Wangaya Kaja Denpasar Utara pada bulan Oktober-November 2019. Besar sampel dihitung menggunakan rumus Slovin dengan jumlah sampel sebanyak 99 lansia dari 114 populasi lansia. Sampel dipilih menggunakan teknik non probability sampling yaitu purposive sampling.Lansia yang selama dilakukan penelitian berpindah tempat tinggal, sedang sakit/dirawat di RS dan lansia dengan ketergantungan total tidak dijadikan sampel.Data demografi (usia, jenis kelamin, pendidikan, pekerjaan), pengetahuan, perankader dan jarak rumah lansia ke posyandu lansia diperoleh dengan teknik menyebarkan kuesioner sedangkan kehadiranlansia diperoleh berdasarkan absensi kehadiran selama satu tahun terakhir. Pertanyaan terkait peran kader terdiri atas tujuh kategori dengan jawabanya dan tidak, lima pertanyaan terkait jarak dengan jawabannya dan tidak serta 11 pertanyaan terkait pengetahuan lansia tentang posyandu. Analisis multivariate dengan regresi logistik dilakukan untuk mendapatkan POR usia, pendidikan dan perankader. Penelitian ini telah mendapat ijin dari Dinas Penanaman modal dan Pelayanan Terpadu Satu Pintu dengan nomor 070/09757/DPMPTSP-B/2019 serta rekomendasi penelitian dari Pemerintah Kota Denpasar.

\section{HASIL DAN PEMBAHASAN Hasil}

Pada Tabel 1, disajikan data karakteristik berdasarkan usia, sebagian besar responden berusia 60-74 tahun yaitu sebanyak 68 orang $(68,69 \%)$. Karakteristik berdasarkan jenis kelamin, responden lakilaki lebih banyak dari pada responden responden perempuan yaitu 52 orang $(52,53 \%)$. Dilihat dari pendidikan, didapatkan bahwa sebagian besar responden berpendidikan SD sebanyak 39 orang $(39,39 \%)$. Karakteristik responden berdasarkan pekerjaan, didapatkan hasil sebagian besar responden yang sudah tidak bekerja yaitu sebanyak 92 orang $(92,93 \%)$.

Pada tabel 2 terlihat bahwa usia dengan POR=0,17 (95\%CI: 0,03-0,94), pendidikan $\mathrm{POR}=2,71 \quad(95 \% \mathrm{CI}: 1,23-6,01)$ dan peran kader $\mathrm{POR}=59,64 \quad$ (95\%CI: 9,18-387,41) merupakan faktor yang berhubungan dengan kepatuhan lansia dalam pemanfaatan pelayanan posyandu lansia. Beberapa factor yang tidak terbukti secara statistic berhubungan dengan kepatuhan lansia dalam pemanfaatan pelayanan posyandu lansia adalah jenis kelamin dengan $\mathrm{p}$-value: 0,552 , pekerjaan dengan $\mathrm{v}$ value: 0,490, jarak rumah ke lokasi posyandu dengan p-value: 0,998 dan pengetahuan dengan p-value: 0,894 . 
Jurnal Akademka Baiturrahim Jambi (JABJ) Vol 10, No 2, September 2021

DOI : 10.36565/jab.v10i2.306

p-ISSN: $2302-8416$

e-ISSN: 2654-2552

Tabel 1 Karakteristik Lansia Di Banjar Wangaya Kaja Tahun 2019

\begin{tabular}{clcc}
\hline No & Karakteristik & Frekuensi (f) & Presentase (\%) \\
\hline 1 & Usia & & \\
& 60-74 th & 68 & 68,69 \\
& $75-90$ th & 31 & 31,31 \\
& Jenis Kelamin & & \\
& Laki-laki & 52 & 52,53 \\
& Perempuan & 47 & 47,47 \\
& Pendidikan & & 39,39 \\
& SD & 39 & 24,24 \\
& SMP & 24 & 33,33 \\
& SMA & 33 & 3,03 \\
& PT & 3 & 7,07 \\
& Pekerjaan & & 92,93 \\
\hline & Bekerja & 7 & 100,00 \\
\hline
\end{tabular}

Tabel 2 Hubungan Variabel Independen dengan Kepatuhan Lansia Menghadiri Posyandu Lansia

\begin{tabular}{|c|c|c|c|c|c|c|c|c|c|c|}
\hline \multirow{3}{*}{ Variabel } & \multicolumn{8}{|c|}{ Kepatuhan } & \multirow{3}{*}{$\mathrm{p}$ value } & \multirow{3}{*}{ POR $(95 \% \mathrm{Cl})$} \\
\hline & \multicolumn{2}{|c|}{ Kepatuhan tinggi } & \multicolumn{2}{|c|}{$\begin{array}{l}\text { Kepatuhan } \\
\text { sedang }\end{array}$} & \multicolumn{2}{|c|}{$\begin{array}{l}\text { Kepatuhan } \\
\text { rendah }\end{array}$} & \multicolumn{2}{|c|}{ Jumlah } & & \\
\hline & $f$ & $\%$ & $f$ & $\%$ & $f$ & $\%$ & & & & \\
\hline \multicolumn{11}{|l|}{ Usia } \\
\hline & & & & & & & & & & 0,17 \\
\hline $60-74$ th & 4 & 5,88 & 25 & 36,76 & 39 & 57,35 & 68 & 68,69 & 0,004 & $(0,03-0,94)$ \\
\hline $75-90$ th & 1 & 3,23 & 3 & 9,68 & 27 & 87,10 & 31 & 31,31 & & \\
\hline \multicolumn{11}{|l|}{ Jenis Kelamin } \\
\hline Laki-laki & 4 & 7,69 & 14 & 26,92 & 34 & 65,38 & 52 & 52,53 & 0,552 & \\
\hline Perempuan & 1 & 2,13 & 14 & 29,79 & 32 & 68,09 & 47 & 47,47 & & \\
\hline \multicolumn{11}{|l|}{ Pendidikan } \\
\hline & & & & & & & & & & 2,71 \\
\hline SD & 1 & 2,56 & 5 & 12,82 & 33 & 84,62 & 39 & 39,39 & 0.000 & $(1,23-6,01)$ \\
\hline SMP & 0 & 0,00 & 5 & 20,83 & 19 & 79,17 & 24 & 24,24 & & \\
\hline SMA & 1 & 3,03 & 18 & 54,55 & 14 & 42,42 & 33 & 33,33 & & \\
\hline PT & 3 & 100,00 & 0 & 0,00 & 0 & 0,00 & 3 & 3,03 & & \\
\hline \multicolumn{11}{|l|}{ Pekerjaan } \\
\hline Bekerja & 1 & 14,29 & 2 & 28,57 & 4 & 57,14 & 7 & 7,07 & 0,490 & \\
\hline Tidak Bekerja & 4 & 4,35 & 26 & 28,26 & 62 & 67,39 & 92 & 92,93 & & \\
\hline \multicolumn{11}{|l|}{ Jarak Lokasi } \\
\hline Tidak Terjangkau & 0 & 0,00 & 0 & 0,00 & 13 & 100,00 & 13 & 13,13 & 0,998 & \\
\hline Terjangkau & 5 & 5,81 & 28 & 32,56 & 53 & 61,63 & 86 & 86,87 & & \\
\hline \multicolumn{11}{|l|}{ Peran Kader } \\
\hline & & & & & & & & & & 59,64 \\
\hline Peran Baik & 5 & 15,63 & 22 & 68,75 & 5 & 15,63 & 32 & 32,32 & 0,000 & $(9,18-387,41)$ \\
\hline Peran Kurang & 0 & 0,00 & 6 & 8,96 & 61 & 91,04 & 67 & 67,68 & & \\
\hline \multicolumn{11}{|l|}{ Pengetahuan } \\
\hline Baik & 5 & 9,62 & 21 & 40,38 & 26 & 50,00 & 52 & 52,53 & 0,894 & \\
\hline Cukup & 0 & 0,00 & 6 & 15,79 & 32 & 84,21 & 38 & 38,38 & & \\
\hline Kurang & 0 & 0,00 & 1 & 11,11 & 8 & 88,89 & 9 & 9,09 & & \\
\hline
\end{tabular}




\section{Pembahasan}

Variabel yang terbukti secara statistic sebagai faktor kepatuhan lansia dalam pemanfaatan posyandu lansia adalah usia, pendidikan dan peran kader. Pada penelitian ini, semakin muda usia lansia semakin patuh dalam memanfaatkan posyandu lansia. Berdasarkan hasil bivariat, sebanyak $87,10 \%$ lansia usia 75-90 tahun berada pada kepatuhan rendah. Tujuan lansia dating keposyandu lansia selain memeriksakan kondisi kesehatan, juga untuk silaturahmi dengan teman-teman seusianya maupun dengan petugas Kesehatan. Hasil penelitian ini sejalan dengan peneltian cross sectional yang dilakukan Anggraini di Ngentak yang mendapatkan bahwa usia yang semakin bertambah membuat lansia tidak bias aktif dalam kegiatan posyandu lansia(Anggraini, 2016).

Pertambahan usia akan menimbulkan perubahan-perubahan pada struktur dan fisiologis sehingga menimbulkan kemunduran pada fisik dan psikis lansia(Maryam, 2008). Berbeda dengan penelitian case control di Yogyakarta bahwa lansia yang berumur $>71$ tahun cenderung lebih aktif ke posyandu dibanding yang berumur $<71$ tahun(Lestari, 2011). Responden yang berumur $>71$ tahun lebih aktif dating ke posyandu karena sering merasakan adanya gangguan kesehatan, dan sebaliknya lansia yang lebih muda tidak aktif ke posyandu karena masih merasa sehat, sehingga dating keposyandu kalua merasa tidak enak badan saja(Lestari, 2011). Kemungkinan perbedaan disebabkan oleh metode yang digunakan dimana pada penelitian ini menggunakan cross sectional sedangkan Lestari menggunakan metode case control. Pada penelitian ini juga terdapat perbedaan cara membagi rentang usia lansia yaitu 6074 tahun dan 75-90 tahun sedangkan pada penelitian Lestari, usia lansia dibagi menjadi dua yaitu usia $\geq 71$ tahun dan $<71$ tahun.
Pendidikan merupakan factor kedua yang terbukti secara statistic berhubungan dengan kepatuhan lansia dalam pemanfaatan posyandu lansia. Semakin tinggi tingkat pendidikan lansia, semakin patuh dalam pemanfatan posyandu lansia. Hasil penelitian ini sejalan dengan penelitian cross sectional di Boyolali Jawa Tengah bahwa terdapat hubungan yang signifikan antara pendidikan dengan kehadiran lansia di posyandu lansia. Semakin tinggi pendidikan maka semakin aktif frekuensi kehadiran lanjut usia ke posyandu lansia (Santjaka, 2013). Pendidikan sebagai suatu proses dalam rangkaian mempengaruhi dan menimbulkan perubahan perilaku pada dirinya (Mubarak,2009). Lanjut usia yang mempunyai pendidikan tinggi akan memberikan respon yang lebih rasional dibandingkan lansia yang berpendidikan lebih rendah atau mereka yang tidak berpendidikan Lansia dengan pendidikan yang rendah berdampak pada lemahnya ilmu pengetahuan, informasi-informasi baru mengenai kesehatan hal ini akan berdampak juga pada kunjungan keposyandu lansia. Berbeda dengan penelitian case control di Yogyakarta bahwa tingkat pendidikan tidak terbukti sebagai faktor yang mempengaruhi keaktifan kunjungan lansia ke posyandu (Lestari, 2011). Perbedaan tersebut kemungkinan disebabkan oleh distribusi tingkat pendidikan sama persis antara kasus dan kontrol, dengan jumlah yang terbesar adalah pendidikan $<$ SMP $80,8 \%$.

Peran kader merupakan factor ketiga yang berhubungan dengan kepatuhan lansia dalam pemanfaatan posyandu lansia dimana semakin baik peran kader meningkatkan 59 kali kepatuhan lansia. Sejalan dengan penelitian yang dilakukan oleh Anggraini bahwa pelayanan kader memiliki hubungan dengan keaktifan lansia mengikuti kegiatan posyandu (Anggraini, 2016). Kader kesehatan bertanggung jawab terhadap masyarakat setempat, mereka bekerja dan 
berperan sebagai seseorang pelaku dari sebuah sistem kesehatan. Kader bertanggung jawab kepada kepala desa dan supervisor yang ditunjuk oleh petugas/tenaga pelayanan pemerintah. Kader masyarakat merupakan salah satu unsur yang memiliki peranan penting dalam pelayanan kesehatan dimasyarakat (Sulistyorini,2010). Kader lansia merupakan suatu penggerak terpenting dalam menjalankan tujuan yang dimiliki poyandu lansia tersebut. Kader mempunyai peran sebagai pelaku dari sebuah sistem kesehatan, kader diharapkan bisa memberikan berbagai pelayanan yang meliputi pengukuran tinggi dan berat badan, pengukuran tekanan darah, pengisian lembar Kartu Menuju Sehat (KMS), memberikan penyuluhan atau penyebarluasan informasi kesehatan, menggerakkan serta mengajak usia lanjut untuk hadir dan berpartisipasi dalam kegiatan Posyandu Lansia (Sulistyorini, 2010). Berbeda dengan penelitian Bukit di Pekanbaru bahwa tidak ada hubungan antara peran petugas salah satunya peran kader dengan keaktifan lansia mengikuti kegiatan posyandu di Puskes madengan 2,203 (0,88-5,47) (Bukit, 2019). Kemungkinan perbedaan hasil disebabkan oleh faktor lain yang berpengaruh salah satunya adalah masih rendahnya kesadaran lansia dalam pemanfaatan posyandu lansia walau pun peran kader dalam memberikan informasi sudah baik.

Pada penelitian ini didapatkan bahwa beberapa variabel tidak terbukti secara statistik merupakan faktor kepatuhan lansia dalam pemanfaatan posyandu lansia yaitu jenis kelamin, pekerjaan, jarak lokasi ke posyandu lansia dan pengetahuan. Pada penelitian ini, jenis kelamin tidak terbukti sebagai faktor kepatuhan lansia dalam pemanfaatan posyandu lansia dengan $p$ value: 0,552. Pada penelitian ini jumlah laki-laki dan perempuan tidak jauh berbeda yaitu 52 lansia dan 47 lansia. Hal ini menunjukkan bahwa lansia perempuan dan laki-laki memiliki kesamaan dalam bereaksi terhadap gejala, penyakit, maupun kondisi lain yang mengganggu dan menyebabkan mereka harus mengunjungi pelayanan Kesehatan.

Pekerjaan tidak terbukti secara statistik sebagai faktor kepatuhan lansia dalam pemanfaatan posyandu lansia dengan p value: 0,490. Pada penelitian ini, jumlah lansia yang masih aktif bekerja menghasilkan uang adalah sejumlah 7,07\%. Penelitian lain juga mendapatkan hasil yang serupa, dimana pekerjaan tidak memiliki hubungan dengan keaktifan lansia mengikuti kegiatan posyandu(Anggraini, 2016) Bekerja merupakan kegiatan utama untuk pemenuhan kebutuhan hidupnya sehingga lansia mengabaikan untuk ikut berpartisipasi dalam kegiatan posyandu lansia. Berbeda dengan penelitian Lestari dimana terdapat hubungan antara pekerjaan dengan pemanfaatan posyandu lansia. Lansia yang sudah tidak bekerja cenderung lebih aktif ke posyandu dibanding yang masih bekerja (Lestari, 2011) Perbedaan hasil penelitian kemungkinan disebabkan oleh perbedaan budaya khususnya masyarakat Bali yang masih menggunakan system extended family, dimana orang tua tinggal satu rumah dengan anak laki-laki. Salah satu tugas yang diberikan kepada orang tua oleh anaknya adalah menjaga cucu di rumah sampai anak pulang dari tempat kerja. Rata-rata jam pulang kerja adalah jam enam sore yang bertepatan dengan waktu dilaksanakan posyandu lansia, sehingga lansia berhalangan mengikuti posyandu lansia.

Pada penelitian ini, jarak bukan merupakan salah satu factor kepatuhan lansia dalam pemanfaatan posyandu lansia dengan p-value 0,998. Studi cross sectional di Riau menunjukkan bahwa tidak terdapat hubungan antara jarak dengan minat lansia mengunjungi posyandu lansia (Ningsih, 2014). Sejalan Penelitian (Melita \& Nadjib, 2018) yang menunjukkan bahwa tidak ada hubungan antara jarak/aksesibilitas dengan 
pemanfaatan posyandu lansia. Sebagian besar masyarakat memanfaatkan posyandu lansia sebagai pelayanan kesehatan khusus lansia, karena jarak rumah masyarakat dengan posyandu lansia terjangkau atau dekat. Jarak tempuh merupakan salah satu factor penentu untuk dapat memanfaatkan pelayanan kesehatan yaitu salah satunya posyandu lansia, namun masih terdapat lansia yang tidak memanfaatkan posyandu lansia. Jarak posyandu lansia adalah rentang lokasi antara tempat tinggal lansia dengan tempat kegiatan pelayanan Kesehatan khususnya posyandu lansia. Jarak Posyandu yang dekat akan membuat lansia mudah menjangkau Posyandu lansia. Kemudahan dalam menjangkau lokasi Posyandu lansia ini berhubungan dengan factor keamanan atau keselamatan bagi lansia. Jika lansia merasa aman atau merasa mudah untuk menjangkau lokasi posyandu tanpa harus menimbulkan kelelahan atau masalah yang lebih serius, maka hal ini dapat mendorong minat lansia untuk mengikuti kegiatan posyandu lansia(Sulistyorini, 2010).

Berbeda dengan penelitian yang dilakukan oleh Sayati bahwa terdapat hubungan yang signifikan antara jarak/aksesibilitas dengan pemanfaatan posyandu lansia di wilayah kerja Puskesmas 7 Ulu Palembang Palembang tahun 2017(Sayati, 2018). Jarak posyandu lansia adalah rentang lokasi antara tempat tinggal lansia dengan tempat kegiatan pelayanan kesehatan khususnya posyandu lansia(Sulistyorini, 2010). Jarak dan akses mudah dijangkau oleh lansia namun masih banyak lansia yang tidak aktif keposyandu lansia kemungkinan dipengaruhi faktor lain yaitu ada tidaknya keluarga atau orang rumah yang mengantar ke balai pertemuan tempat diadakannya posyandu lansia.

Pada penelitian ini, pengetahuan tidak terbukti secara statistic sebagai factor kepatuhan lansia dalam pemanfaatan posyandu lansia dengan p-value: 0,894. Berbeda dengan hasil penelitian yang dilakukan oleh (Aryatiningsih, 2014) tentang faktor-faktor yang berhubungan dengan pemanfaatan posyandu lansia di Kota Pekan Baru, yang menunjukkan hasil bahwa terdapat hubungan antara pengetahuan dengan pemanfaatan posyandu lansia. Pengetahuan adalah hasil tahu seseorang terhadap objek melalui indera yang dimilikinya (mata, hidung, telinga, dan sebagainya), atau hasil penginderaan manusia. Pengetahuan yang dihasilkan tersebut dipengaruhi oleh lamanya intensitas perhatian dan persepsi terhadap objek (Notoadmodjo, 2012). Terdapat beberapa lansia yang berpengetahuan baik tetapi tidak dating ke posyandu disebabkan karena berbagai factor yaitu jadwal posyandu yang bersamaan dengan kegiatan lansia. Faktor lain yang kemungkinan berpengaruh yaitu tempat peneliti melaksanakan penelitian berada di areal perkotaan dan dekat dengan Puskesmas III Denpasar Utara, oleh sebab itu mereka cenderung mencari pelayanan kesehatan utama di Puskesmas.

Keterbatasan penelitian ini, peneliti belum mampu mengontrol faktor lain yang kemungkinan mempengaruhi hasil penelitian, salah satunya adalah factor budaya.

\section{SIMPULAN}

Terdapat hubungan antara usia POR=0,17 (95\%CI: 0,03-0,94), pendidikan POR $=2,71 \quad(95 \% \mathrm{CI}: 1,23-6,01)$ dan peran kader $\mathrm{POR}=59,64$ (95\%CI: 9,18-387,41) dengan kepatuhan lansia dalam pemanfaatan pelayanan posyandu lansia. Faktor yang secara statistic tidak ditemukan berhubungan adalah jenis kelamin ( $\mathrm{p}$ value: 0,552), pekerjaan ( $\mathrm{p}$ value: 0,490$)$, jarak lokasi ke posyandu lansia (p-value: 0,009$)$ dan pengetahuan ( $\mathrm{p}$ value: 0,894$)$.

\section{SARAN}

Kader lebih meningkatkan perannya seperti melakukan kunjungan 
rumah, sebagai motivator sebagai salah satu upaya meningkatkan pelayanan posyandu lansia.

\section{DAFTAR PUSTAKA}

Amaral, A., Wiyono, J., \& Candawati, E. (2017). Analisis Faktor Kehadiran Lansia dalam Mengikuti Posyandu di Desa Pagersari Kecamatan Ngantang Kabupaten Malang. Nursing News, 2(2), 71-79.

Anggraini, D., Zulpahiyana, Z., \& Mulyanti, M. (2016). Faktor Dominan Lansia Aktif Mengikuti Kegiatan Posyandu di Dusun Ngentak. Jurnal Ners Dan Kebidanan Indonesia, 3(3), 150.

https://doi.org/10.21927/jnki.2015.3(3) .150-155

Aprilla, V., Afandi, D., Putri Damayanti, I., Hang Tuah Pekanbaru, Stik., \& BaruIndonesia, P. (2019). Faktor Yang Berhubungan Dengan Kunjungan Lansia Ke Posyandu Lansia Tahun 2019.

Aryatiningsih, D. S. (2014). Faktor-Faktor Yang Berhubungan Dengan Pemanfaatan Posyandu Lansia Di Kota Pekanbaru. An-Nadaa, 1(2), 42-47.

Bukit, R. B. (2019). Faktor-Faktor Yang Mempengaruhi Kunjungan Posyandu Lansia Di Puskesmas Tenayan Raya Pekanbaru Tahun 2018. Jurnal Kesehatan Husada Gmilang, 1(1), 6.

Departemen of Economic and Social Affairs. World Population Prospects The 2015 Revision. Key Findings and Advance Tables.2015.

Lestari, P., Hadisaputro, S., \& Pranarka, K. (2011). Beberapa Faktor Yang Berperan Terhadap Keaktifan Kunjungan Lansia Ke Posyandu Studi Kasus Di Desa Tamantirto Kecamatan Kasihan Kabupaten Bantul Propinsi Diy. Media Medika Indonesiana, 45(2), 74-82.

Kemenkes RI. Pusat Data dan Informasi Kementerian Kesehatan RI, Situasi dan analisis Lanjut Usia. Pusdatin, p. 8. https://doi.org/10.1016/S0169409X(97)00122-1.2014

Kemenkes RI. Analisis Lansia di Indonesia. Pusat Data Dan Informasi Kementerian Kesehatan RI, 1-2. Retrieved from www.depkes.go.id/download.php?file =download $/ .$. /infodatin lansia 2016.pdf\%0A.2017

Kemenkes RI. Profil Kesehatan Indonesia 2018 [Indonesia Health Profile 2018]. Retrieved from http://www.depkes.go.id/resources/do wnload/pusdatin/profil-kesehatanindonesia/Data-dan-Informasi_ProfilKesehatan-Indonesia-2018.pdf.2019.

Maryam, S. Menengenal Usia Lanjut dan Perawatannya (p. 220). p. 220. Retrieved from https://books.google.co.id/books?id=jx pDEZ27dnwC.2008.

Melita, \& Nadjib, M. (2018). Faktor-faktor yang Berhubungan dengan Kunjungan Lansia ke Posbindu Lansia di Wilayah Kerja Puskesmas Kelurahan Bintara Kota Bekasi tahun 2017. Jurnal Kebijakan Kesehatan Indonesia, 07(04), 158-167.

Mubarak.W.I. Ilmu Kesehatan Masyarakat Teori dan Aplikasi. Jakarta: Salemba Medika.2009.

Ningsih.R, Arneliwati, Lestari.W (2014).Faktor faktor yang Mempengaruhi Minat Lansia Mengunjungi Posyandu lansia. JOM PSIK Vol. 1 No. 2

Notoatmodjo, Soekidjo. Pendidikan dan Perilaku Kesehatan. Jakarta: Rineka Cipta.2.2012.

Santjaka, H. I., Walin, \& Handayani, R. (2013). Proses Menua. Bidan Prada: Jurnal Ilmu Kebidanan, 4(1), 1.

Sayati, D. (2018). Fakto-faktor yang berhubugan dengan pemanfaatan posyandu lansia di puskesmas $7 \mathrm{Ulu}$ Pelembang Tahun 2017. Jurnal 'Aisyiyah Medika, 1(2), 166-177. 
Retrieved from http://jurnal.stikesaisyiyahpalembang.ac.id/index.php/JA M/article/download/20/16

Sulistyorini, C. I. S. P. Posyandu dan Desa Siaga: Panduan untuk Bidan dan Kader (-.). Yogyakarta: Nuha Medika.2010

Undang-Undang Republik Indonesia No 36. Kesehatan.2009.

WHO. (2017). World Health Organization, Elderly Population. Searo. 